\title{
Construction of Robot Practice Teaching System Based on CDIO Model
}

\author{
Ti Han $^{\mathrm{a}}{ }^{*}$, Lei Luo ${ }^{\mathrm{b}}$, Guoshun Zhouc and Baowei Lin ${ }^{\mathrm{d}}$ \\ Electronic Engineering Department, Dalian Neusoft University of Information, Dalian, China \\ ahanti@neusoft.edu.cn, bluolei@neusoft.edu.cn, czhouguoshun@neusoft.edu.cn, \\ dlinbaowei@neusoft.edu.cn
}

Keywords: CDIO; Robot; Practice Teaching; Intelligent science

\begin{abstract}
Aiming at the characteristics of students of Intelligent Science and Technology, introduce the project oriented education concept, combining CDIO engineering education concept with innovation and pioneering in the current high education field, the four-years practice teaching model of intelligent robot is proposed on undergraduate course education field. The whole implementing process of practice teaching is introduced including structural basis, the design of project content, concrete measures of the project, ability cultivation, teaching organizational form and evaluation methods. Giving examples of quadruped robot, the process of the practice course is illustrated. The type of the project is from simple too complex to improve the students' engineering practice ability of Intelligent Science.
\end{abstract}

\section{Introduction}

With the continuous development of the field of global intelligence and the rise of the robot industry, social and enterprise demand for intelligent product application talents is increasing day by day. However, there is no clear goal of training talents in Colleges and universities, the curriculum system lags behind the development of technology, the old teaching methods and means, the lack of practical teaching, the evaluation system dislocation and so on, which leads to the theory of engineering education, the training direction of the school is not in conformity with the industrial demand. In order to effectively solve this problem, after further study and exploration, the concept of CDIO engineering education is a new idea of international engineering education reform, which provides a new idea of curriculum reform for the development of engineering higher education.

In accordance with the concept of CDIO Engineering Education, combined with advanced concepts in intelligent science-- the new theory, new technology, new tools, and the new products, the course system and teaching content of intelligent science and technology are updating, a series of special practice courses that are different from other universities are set up. So students can master the technology of intelligent industry, the students' innovation spirit and engineering practice ability have been strengthened, thus there is a favorable position in the employment market.

\section{Localization of CDIO Teaching Mode}

The CDIO(Conceive, Design, Implement, Operate) model is the engineering education model which was founded in 2000, which inherits and develops the educational reform ideas in Europe and America in recent years. It is the development direction of Engineering Education in the world, has been widely used in the engineering colleges and universities in China. CDIO is universal but rooted in European and American countries, so need to make adjustments combined with the actual situation, according to China's educational and cultural environment $[1,2]$.

The purpose of engineering education reform is to cultivate students' ability to conceive, design, implement and operate process and system in engineering practice, to enable students to graduate from the university with the basic engineering innovation and design capabilities, with the basic quality of Engineers[3, 4]. In order to achieve this goal, we must reform the teaching methods in the course of traditional education which makes theory divorce from practice, also to add personal 
accomplishment, team cooperation and system construction ability. Therefore, Dalian Neusoft University of Information innovation, adjust and increase the capacity of some indicators in 2009, the TOPCARES-CDIO engineering education system was developed based on engineering practice ability. TOPCARES is the first of the 8 CDIO level capability indicators of the first letter combination, that is, Technical knowledge and reasoning, Open thinking and innovation, Personal and professional skills, Communication and teamwork, Attitude and manner, Responsibility, Ethical values, Social contribution by application practice. In the college CDIO teaching engineering environment, education and teaching reform are carried out in intelligent science and technology major, and achieved good results[5, 6].

\section{Design of Intelligent Robot Practice Project}

Adhere to project oriented, design and implementation of the project run throughout the four years of teaching in the University. Each school year is divided into three semesters, the two semester of theoretical teaching, the third semester to carry out practical teaching. In the practice term, students carry out courses or professional comprehensive project training under the guidance of teachers. On the basis of the practice training of three years of study, full implement the project in the fourth year, in order to strengthen students' professional practice skills, thus allow students to have a year of work experience before graduation.

According to the characteristics of the students of intelligence technology, intelligent robot system design as the main line, design of practical projects has been carried out. In accordance with the practice system of basic ability training, professional ability training, comprehensive ability training, project training step by step, implement the four years of practice courses (illustrated in Fig. 1).

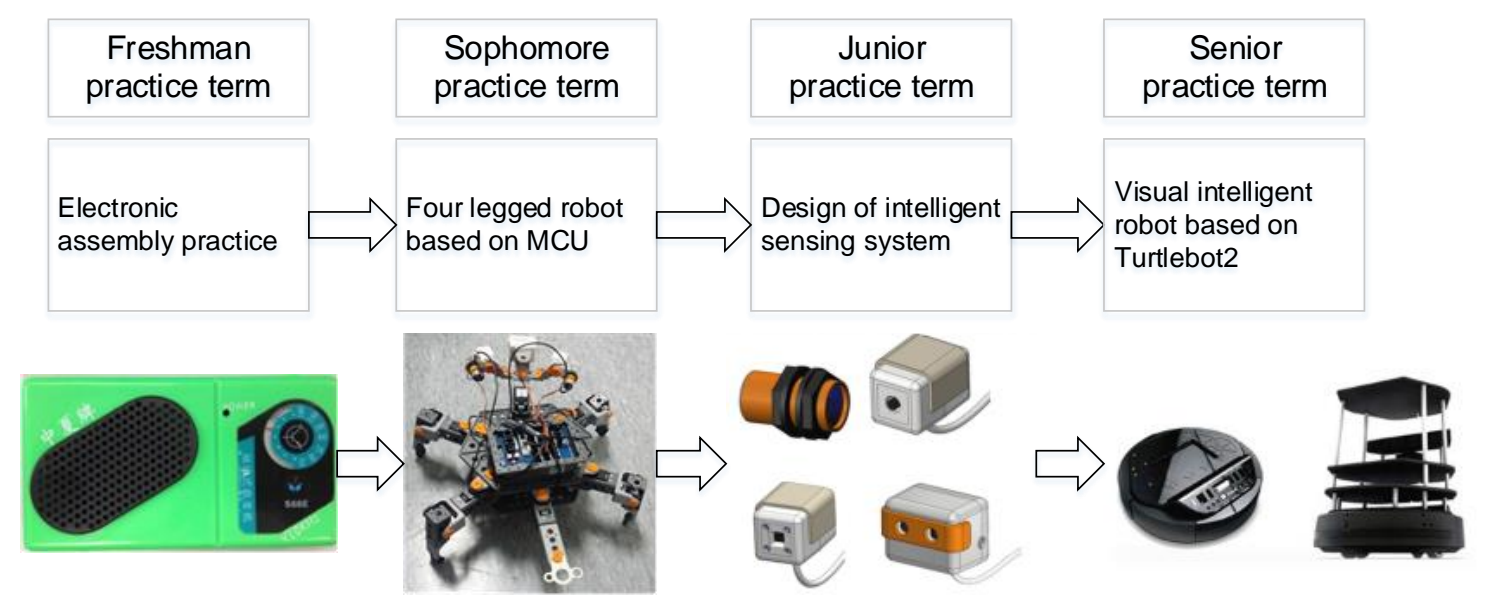

Figure 1. Professional practice project progression diagram

\section{Implementation of Intelligent Robot Practice Project}

This paper takes a four legged robot based on MCU project as an example. The goal of the project is to make the students understand the process of the development of the robot project based on single chip microcomputer, master the basic knowledge and skills needed for the project development of intelligent robot system, skilled use of programming, microcontroller, sensors and other theoretical knowledge, and apply it to practical engineering, improve students' practical ability and the ability to solve problems by using knowledge. In this project, students will use the robot to build a four legged robot to complete the debugging of single chip microcomputer and sensor, and able to complete the walk, tracking, obstacle avoidance and other functions. After the completion of the function, the students use the robot kit and MCU platform for the design of new features, complete at least one of the additional features of innovative thinking. 
According to the characteristics of practical courses of the combination of theory and practice,choose ability indicators in the CDIO eight indicators system to fit in practical course, as the ability index of curriculum development. Ability index covers three major types of ability including theoretical knowledge, professional quality and professional skill(the ability indicators selected are shown in Table 1). The traditional theoretical courses are usually based on the theory of knowledge, the practice course is the opposite, mainly to cultivate professional skills, theoretical knowledge and professional literacy as a supplement $[7,8]$.

Table 1 Capability Index

\begin{tabular}{|l|l|l|}
\hline $\begin{array}{l}\text { 1st Stage Capability } \\
\text { Index }\end{array}$ & $\begin{array}{l}\text { 2nd Stage Capability } \\
\text { Index }\end{array}$ & 3rd Stage Capability Index \\
\hline $\begin{array}{l}\text { Technical knowledge and } \\
\text { reasoning }\end{array}$ & $\begin{array}{l}\text { Professional } \\
\text { knowledge }\end{array}$ & Intelligent information processing system development \\
\hline $\begin{array}{l}\text { Open thinking and } \\
\text { innovation }\end{array}$ & Innovation capability & $\begin{array}{l}\text { Introduction, digestion, absorption and re-innovation } \\
\text { capability }\end{array}$ \\
\hline \multirow{3}{*}{$\begin{array}{l}\text { Personal and professional } \\
\text { skills }\end{array}$} & $\begin{array}{l}\text { Engineering reasoning } \\
\text { and problem solving } \\
\text { capability }\end{array}$ & Finding and expressing problems \\
\hline \multirow{4}{*}{$\begin{array}{l}\text { Communication and } \\
\text { teamwork }\end{array}$} & $\begin{array}{l}\text { Communication } \\
\text { capability }\end{array}$ & Written communication \\
\cline { 2 - 3 } & $\begin{array}{l}\text { Foreign language } \\
\text { using capability }\end{array}$ & Reading and understanding of the professional literatures \\
\cline { 2 - 3 } & Team Work & Building Technical Team \\
\hline \multirow{2}{*}{ Attitude and manner } & $\begin{array}{l}\text { Professional attitudes } \\
\text { and habits }\end{array}$ & Seeking truth from facts \\
\hline \multirow{3}{*}{$\begin{array}{l}\text { Social contribution by } \\
\text { application practice } \\
\text { (CDIO) }\end{array}$} & Conceive & System modeling \\
\cline { 2 - 3 } & Design & Segmentation and method of design process \\
\cline { 2 - 3 } & Implement & Hardware implementation process \\
\cline { 2 - 3 } & Software implementation process \\
\cline { 2 - 3 } & Operate & System improvement and evolution \\
\hline
\end{tabular}

Students can not only more deeply understand previous theoretical knowledge in theoretical semester, but also use learned knowledge and skills on actual projects such as microcontroller system design, etc., through the implementation of the project. Design and implementation of the function of robot are completed through the analysis of project requirements. Capabilities of practicing, knowledge applying to solve problems as well as technical documents writing are all improved, reaching the capability progressive training needs. As shown in Fig. 2.

\section{Organization Form of Practice Teaching}

CDIO advocates active learning and experience learning in order to solve the problem of theory and practice $[8,9]$. Active learning is to allow students directly participate in the learning activity and at the same time to think and solve problems, the main manifestation is teachers collect and feedback students' learning problems; teachers take questions before class, guide students to solve problems in class. Experiential learning approach is to allow students take learning activities in the environment of the simulation engineers and engineering, including project based learning, simulation, case analysis and design, including:

(1) Using teaching, demonstration teaching, case teaching, cooperative learning, self-learning methods. Combing theory and practice, teachers guide students to explore new ideas, and students 
complete the analysis, design, manufacture and test of the whole process, as well as the project summary report, and finally reply in groups.

(2) Based on the CDIO engineering education concept, using project oriented to organize teaching, taking project operation standard into teaching process through the task driven.

(3) Providing rich educational resources, such as courseware, reference materials, network resources, etc. during the process of teaching.

(4) Combining with the course implementation process, carrying out a full range of assessment to students from knowledge mastery, ability level, attitude etc..

(5) Each student must complete function and display the creativity in addition to the provisions of the work, outstanding works participate in practice term works show and subsequent selected outstanding groups participate in the national level intelligence science competition, encouraging students to actively participate in the competition to help students plan to the career direction.

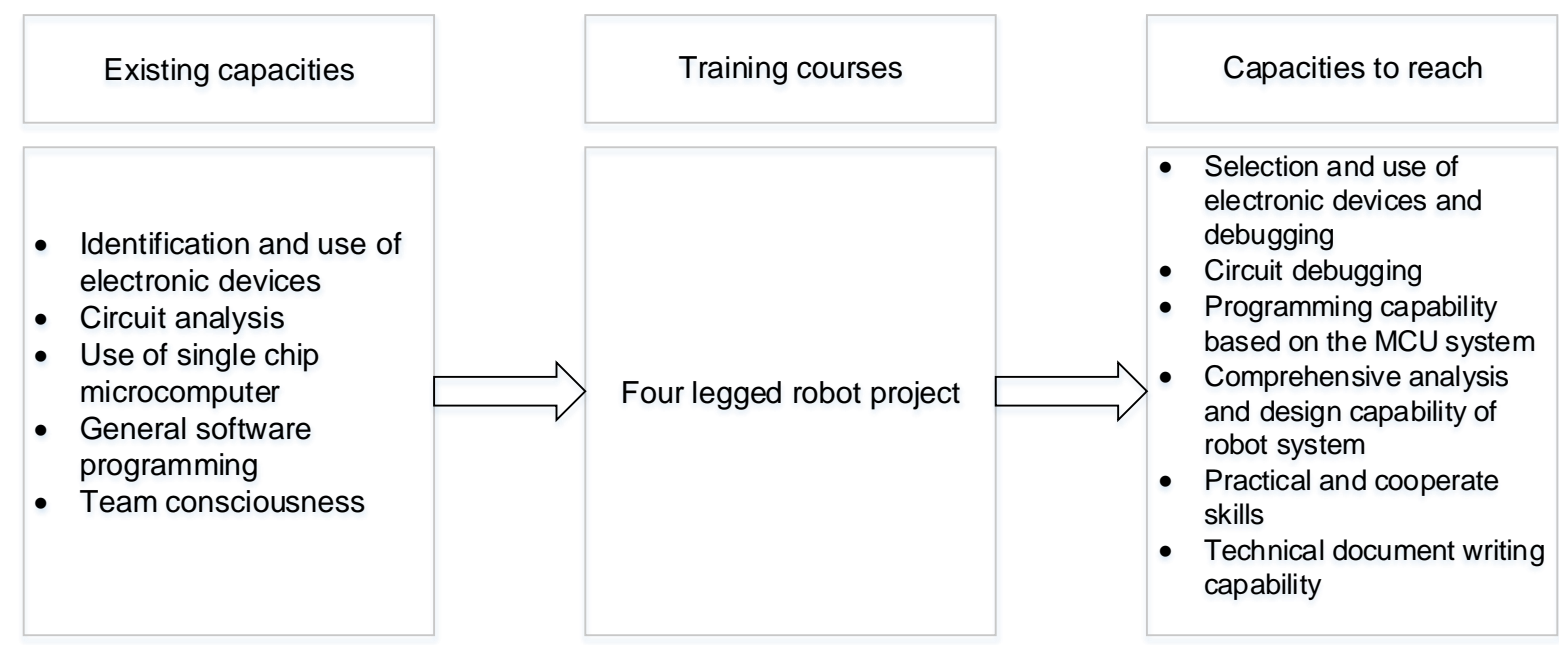

Figure 2. Ability progression diagram

\section{Evaluation System of Practice Teaching}

Assessment and evaluation is to measure the degree of students' learning effect. Traditional teaching evaluation is basically completed by the written examination, this assessment is difficult to evaluate the student's engineering, product and process building capacity[9, 10]. The evaluation of CDIO teaching mode is based on learning, which runs through the whole teaching process. Main evaluation methods can be written, oral, usual performance, project results and written reports, etc.. According to the final assessment results, teachers will continue to improve the teaching outline and teaching methods, which will form a closed loop control system. The evaluation of practical project should pay attention to assessment. Scores should be refined to results of each process of the project implementation, in order to distinguish between the different contributions of each team members, process score to each of the group members are in accordance with the weight respectively. Above is shown as Table 2.

Table 2 Project score table

\begin{tabular}{|c|l|c|}
\hline Category & \multicolumn{1}{|c|}{ Items } & Values(scores) \\
\hline \multirow{4}{*}{ Formative Assessment } & Material collection and reading & 10 \\
\cline { 2 - 3 } & Development environment establishment & 5 \\
\cline { 2 - 3 } & Teamwork & 5 \\
\cline { 2 - 3 } & Project Practice Process & 40 \\
\hline \multirow{3}{*}{ Final Examination } & Design Report & 15 \\
\cline { 2 - 3 } & Reply & 15 \\
\cline { 2 - 3 } & Project Results & 10 \\
\hline
\end{tabular}




\section{Conclusion}

Intelligent science and technology major is a new undergraduate major. Using CDIO model to carry out the reform of practical teaching design, students' professional technical ability and engineering practice ability have been significantly improved. The number of winning students in all levels of competition is increasing year by year, has received the cooperation enterprise's consistent high praise.

Practice has proved that, based on the CDIO engineering education mode gradually reform the practice teaching mode in the field of intelligent major. The talent training mode of project oriented integration and the cultivation mode of innovative talents with integration of production and learning, both ensure that students get the knowledge and skills of the industry, and systematic training students' practical ability, innovation ability and professional quality. It is of great significance to cultivate innovative talents. However, due to the reform of the practice project has just started, although it has achieved some success, still need to gradually explore the details of the implementation of specific programs, to make it better adapt to the needs of professional personnel training.

\section{Acknowledgements}

Project supported by the Project of Engineering talent training mode reform of College of general higher education of Liaoning Province of China in 2012 (No. GZ201249).

\section{References}

[1] Wen Tao. The exploration and practice of integrated talents nurturing model based on TOPCARES-CDIO [J]. Computer Education, 11 (2010) 23-29.

[2] Office of the working group on the outline of educational planning. Education plan for learning counseling education [M]. Beijing: Education Science Press, (2011)

[3] Zhang Qi. Psychology of higher education [M]. Dalian: Liaoning Normal University press. 2007

[4] Edward F. Crawley, Johan Malmqvist, Soren Ostlund, Doris R, Brodeur .Rethinking Engineering Education: The CDIO Approach[M]. New York:Springer, (2007) 77-129.

[5] Information on http://cdio.org/cdio-syllabus-rept/index.html

[6] Information on http://www. moe. edu. cn/edoas/website18/zhuanti/2010zqyj/zqyjg.htm.

[7] Zhemin Zhuang, Yajuan Tang, Minfen Shen, Cornerstone Conceive for electronic enginering Fresher- Experience with CDIO innovation and project, Proceedings of the 4rd International CDIO Conference, University College Ghent(Hoge school Gent), Belgium, 6(2008)16-19

[8] Baowei Lin. Curriculum planning for the introduction of intelligent science and technology [J]. Computer Education. 18(2015)37-40

[9] Guoshun Zhou. The reform of talent training program of intelligent science and Technology Specialty under CDIO model [J]. Computer Education. 18(2015)14-18

[10] Lin Yizhen. Exploration and analysis of CDIO higher engineering education mode [J]. Journal of Harbin University, 4 (29) (2008) 137-140 